\title{
Social Values and Planning
}

\author{
TAlal M. Al-ShareEF \\ Assistant Professor \\ Department of Public Administration \\ Faculty of Economics and Administration \\ King Abdul-Aziz University, Jeddah, Saudi Arabia
}

\begin{abstract}
Saudi Arabia came to a decision that it should have a plan. It set out with the aim of developing all of the country, taking into a account the benefit of the population as a whole. Saudi special social, religious and ideological characteristics would be maintained through out planning.

The main purpose of this research is to discuss:

1- Saudi customs, religion and traditions which could be obstacles in the way of planning.

2- The attitude of the society towards planning.

3- The nature of the society's response to planning.

It has been found that the objective of Saudi planning is to maximize the welfare of the society at large without rupturing the social value In addition, Saudi attachment to religious and social customs did not slow the progress of planning.
\end{abstract}

\section{Introduction}

Planning is a complete process. The nature of this process is largely influenced by many factors, such as the degree of economic literacy and technical, administrative and managerial competency. But there is one factor which dominates all the above- named, i.e. the country's social values as a conditioning boundary for the effectiveness of planning.

\section{Statement of the Problem}

The most striking change in planning sophistication and priorities, from the First Plan to the Fifth Plan is seen in the priorities for Saudi Society, i.e. social development. Accordingly, it can be argued that the Saudi traditions, customs, and culture could be obstacles in the way of planning. This paper will concentrate on the response of planning to social values and concerns as well as the attitudes and reactions in society to planning in Saudi Arabia. 


\section{Objective of the Research}

The following objectives of this research will be studied:

- Evaluation of the social values as a conditioning boundary for the effectiveness of planning.

- Explanation of the social response to planning.

- Examination of the role of planning in maintaining social values.

The above objectives give rise to the following questions to be answered:

- What are the priorities and objectives of planning in Saudi Arabia?

- What is the relationship between societies and planning bodies?

- What is the attitude of society concerning participation in planning?

- How does planning deal with social values?

\section{Literature Review}

Even though the era of planning can generally be regarded as starting from the beginning of the twentieth century, rather than in any other period of history, the ancient history of mankind shows that in a sense, man tried hard in the earliest societies and states to predict, plan, and to avoid risk. Indeed, it seems that in the past, planning was a major factor for people living in social and economic Communities. For example, Baldwin in his statement on the history of planning, confirms that planning is not an entirely modern concept. There is an indication of planning in Biblical times when Abraham prepared a plan to meet the problems his society faced ${ }^{(1)}$.

Planning has become much better known and more important in this century and especially since the end of the Second World War. It played a huge part in the reconstruction of the Western World and it has come to play a basic role in many countries' economical and social values. Underdeveloped countries have found it necessary to set up plans for their development to improve their social situation and tackle the problems in many sectors.

The main objective reason why planning is especially important in these countries is that in a society where changes in the past have been few and slow, an effort is now being made to obtain rapid change. Therefore, need for seeing that the various government measures fit together sensibly and have the desired impact on development, is much more urgent than in a country whose institutions have long been adjusted to continuing change.

It is very interesting to note that despite the number of articles and books dealing with planning on one level or another, or in one context, a systematic approach to the study of planning is necessary. There are many possible planning styles, and the number of available planning methodologies, instruments and means is very large. In whatever type of planning one has in mind, the characteristics of the context within which planning takes place are critical $^{(2)}$ In this case focus will be concentrated on social planning which is concerned with the process of change and development, in the society. The basic definition, however, of social planning may be stated as organizing the means for increasing the standard of living of the whole population through deliberate steps initiated in the main by government, influencing both economic activity

(1) Claude D. Baldwin, Economic Planning, Urbana: The University of Illinois Press, 1942, p.1.

(2)Yehezkel Dror, "Ventures in Policy Science", N.Y.: American Elsevien Publishing Company, 1970, p. 95 
and the physical environment in so far as is necessary to achieve the overall goals. Additionally, social planning is the limiting or forming of all of the relationships among individuals or groups of individuals in line with some purpose, however determined. Social planning involved the influencing of individuals in order to convince them of the desirability or undesirability of their social aim ${ }^{(3)}$.

In addition, the use of the term social planning is much less frequent in the developed countries of Western Europe ${ }^{(4)}$. It has, neither in the past nor at the present, received much attention in the total process of development planning. This omission or neglect could be due to the fact that it has been tacitly assumed that efforts directed at economic development must produce results in tangible. social benefits. However, the importance of social planning stems from the need to make the most effective use of very limited resources by deciding on certain priorities for action in the full knowledge that these will have immense social consequences. Such plans stem from the need to pursue economic development in ways that will lead to long-term improvement of the nation's manpower for the good of the whole rather than the immediate exploitation of it for short-term private gain; from the need to control the process of urbanization and physical development in order to direct the process of migration from a rural to an urban situation; and from the need to develop a population policy that will equip people with the competence to undertake family planning ${ }^{(5)}$.

Admittedly, social planning is developed with the belief that collective action is needed to advance social welfare. It is still weak both as a body of knowledge and as a theoretical structure and it proceeds through the setting of priorities that cannot be done by economic calculation alone. Social planning operates through political decisions and, therefore, is affected by social norms and the range of social values in a society. The contribution of social planning in the less developed countries assumes that there are specific common needs and goals in society, and that these can be determined and pursued in terms of coherent social and economic policies. Indeed, on this assumption, there is a danger that policy decisions will be subject to arbitrariness and may display important omissions. It is necessary, therefore; that the policies, and the programmes which emerge from them, be constantly tested and evaluated for compatibility. The Second is the problem of urbanization and the accompanying transformation of societies $^{(6)}$.

In order to fully understand planning, there are a number of factors which affect the preparation and execution of the plan, which must he considered in any country before an attempt to plan is undertaken. The constitution of the country, and the ideology and principles of the society which will determine the objectives and goals of planning must be taken into account. For example, a government will give its priorities and goals in advance of the plan being worked out in order that its policies on issues such as education, defence, full employment, the economic situation and health, might be carried out. Several countries regard the constitution with much respect because they consider it as laying down or enriching the way of life and the course they have to

(3) M. J. Bruton, The Spirit and Purpose of planning, London: Hutchinson and Company Ltd., 1974, pp. 115-118.

(4) Ibid, p.120.

(5) Baldwin, op. cit., p.10.

(6) Bruton, op. cit., pp.149-150. 
follow $^{(7)}$. For example, the Saudi Arabian government insists on the over-riding requirement of respecting the constitution which is integral to the society's life.

The ideology or the culture of any society exerts a great deal of influence on planning. The principles of any given political system define its ideologies and these along with the intellectual (including religious) basis of the society, must all be taken into consideration before a plan can be formulated. Cultural factors can strongly affect planning, giving an impetus favourable to planning or being a major obstacle limiting planning activities. For example, when a society feels that planning is very important for creating their future and without it little progress will be made, then the planning will be reinforced. The culture of the society can also contribute to the planning in the sense that people are very well educated and behave rationally. Watson states that the inherent ideology of planning, "is contained in the language and way of thinking. It can be summed up in the word rational" ${ }^{(8)}$.

There are several aspects of a society's culture which must be considered as relevant. The first aspect is that of religion, which is the way of life in certain countries. In these countries, people believe that religion must have a high place among the priorities of planning. For instance, Saudi Arabia has considered religion as the first priority in its five successive development plans since 1970.

The second aspect is the traditions, customs and cultural inheritance which are part of the people and inseparable from the society. It is very difficult to plan without considering the society. Lastly, the transition from being an underdeveloped society to being a developed one must be considered. In most underdeveloped countries people believe in fortune and destiny due to the lack of education, unscientific attitudes and institutions. The dominant things in these countries are rituals, superstition, caste, tradition, custom... etc.; people do not feel inclined to act in a rational way. Thus preparation of planning in these countries must tackle and explain to the people concerned, the advantages of scientific planning ${ }^{(9)}$.

Planning in Saudi Arabia has sought to produce a high rate of economic growth, and emphasis has been placed on the development of human resources through better standards of education, training and health; and, of course, the main goals of planning since it started in 1970 are to transform the material conditions of society whilst, at the same time, preserving its culture and religious values. The government of Saudi Arabia did not want to risk the society's cultural identity while the modern transformation took place, and seems to agree with Braibant who states that,

"It has long been a theoretical ideal that the transnationally induced change should be carefully articulated to the cultural context of the recipient nation. A prerequisite of this is that the recipient nation identify and evaluate its own values and control both the quality and the rate of introduction of outside ideas which will modify these values ${ }^{\prime(10)}$.

Saudi Arabia adopted planning, in a more or less comprehensive sense, because it is concerned with inter-relating society's goals, social institutions, political establishments, environmental factors, human and economic resources and activities

(7) Ahmed S. Ashore, Public Administration, Beirut: Dar Alnahdah Alarabia, 1979, pp, 335-340.

(8) Jack Hayward and Michael Watson, Planning Politics and Public Policy, London: Cambridge University Press, 1975, p. 457.

(9) Ashore, op. cit., p. 335.

(10) Fouad AI-Farsy, Saudi Arabia: A Case Study in Development, London: Stacey International, 1978, p, 21. 
and with placing them in a coherent system of co-ordination. Planning on a comprehensive basis in that way has shown the ability to channel the country from one stage of development to another within specific time periods. In fact, it seems that the planners are very well aware of the responsibility of planning in the future.

\section{Social Values and Planning in Saudi Arabia}

Having investigated planning at a theoretical level in terms of ideals and characteristics, we turn now to focus on the principal issues such as the impact of Islamic religion and social traditions on Saudi planning and to see how religious Ulema and traditions meet with the challenge of planning modernity.

\section{Islamic Religion and Planning}

In the analysis of Saudi society's response to planning it can be concluded that the Islamic religion has had a major impact. Of course, it has largely dominated social life for Moslem people in Islamic countries and especially those of Saudi Arabia, so it is perhaps not surprising that it has affected profoundly the planning process. Islam, in fact, is still the basis of the value system which integrates the various aspects of individual life, as Munis states in his study in Islamic History:

"Islam is suited for all places and times: the authority of Islam must extend to all fields of society, and Islamic doctrines, laws. and systems of ethics are a strong incentive to progress and development" ${ }^{111)}$.

In fact, the Islamic religion serves as the state ideology and encourages private ownership. In Saudi Arabia traditional constraints do exist but the citizen has managed to combine religious and traditional values with the modern way of life, as Huyette emphasises in his book on political adaptation in Saudi Arabia:

"In Saudi Arabia, Islam embodies the religious, social and cultural norms of the people and therefore plays a preponderant role in directing political and social change" ${ }^{\text {"(12) }}$.

As a result of the Islamic domination of the people's life in Saudi Arabia, the religious scholars (Ulama) try to ease any conflict between the requirements of the Islamic law, "Shariah", and the needs of modern legislation. Nafissah has summarized the relationship between the Shariah and the new legislation in Saudi Arabia as follows:

The Ulama in Saudi Arabia, from the outset and without conflict with the political authorities gave the state the freedom to legislate... Any tension that exists between modern legislation and Islamic law is limited to the sphere in which new legislation contradicts the texts of the Koran and Sunna. This tension is not ignored and the general attitude is not to fit social needs to the prevailing interpretation of the texts but rather to reinterpret the texts to accommodate social needs" ${ }^{(13)}$

The Ulama not only formulate the new modern regulations, they also supervise the instruments of political socialization - closely monitoring the education sector, the Mosque and the media to ensure that they instill the proper Islamic values in the new generation. Although the UIama in the beginning opposed education for women as they considered that education for girls led to the degradation of, and immorality in, women

(11) Hani A. Faris, "Heritage and Ideologies in Contemporary Arab Thought: Contrasting Views of Change and Development", Journal of Asian and African Studies, xxi 1-2, 1986, p. 91.

(12) Summer Scott Huyette, Political Adaptation in Saudi Arabia: A Study of the Council of Ministers, London: Westview Press, 1985, p. 8.

(13) Ibid., p. 76. 
and was a revolt against the traditions of society, official recognition of women's right to formal education was in fact accorded in 1960 when King Faisal delivered a speech stating that a decision had been made to open government schools for girls under the control of the Ulama. In fact, the placement of female education under Ulama control was a necessary step to ensure their approval ${ }^{(14)}$.

In accordance with the importance attached to religion by society, and consistent with government policy to promote religious education, there are now three universities which emphasize religious education in addition to the other universities and which are run in accordance with the following principles:

"The purpose of education is to have the student understand Islam in a correct and comprehensive manner, to plant and speed the Islamic creed, to furnish the student with the values, teachings and ideals of Islam, to equip him with various skills and knowledge to develop his conduct in society economically, socially and culturally"(15).

The role of the Ulama is influential in decision-making in Saudi Arabia and they play an important role in both politics and religion because the state and religion are inseparable. They play an influential part in the following departments of government: ${ }^{(16)}$

1. The judicial system.

2. The implementation of the rule of the Islamic law.

3. Religious Guidance Groups with affiliated offices all over the Kingdom.

4. Religious education, that is, Islamic legal education and theology at all levels.

5. Religious jurisprudence.

6. Preaching and guidance all over the nation and abroad.

7. Supervision of girls' education.

8. Religious supervision of all Mosques.

9. Studying scientific and Islamic research.

10. Public notaries.

11. The handling of legal cases in courts according to Islamic law.

Islamic religion and the Ulama, therefore, do not stand as major obstacles to planning in Saudi Arabia. They encourage development in the Kingdom and seek the mutual adaptation of the needs of development and the people's faith. As the ex Minister of Planning states,

"that our Islamic tradition act, not only as a guide but as a source of our development"(17).

So it is clear that Saudi Arabian planning has incorporated the basic principles of the Islamic religion such as the demands on its followers as individual believers and as a nation, to act fraternally, to govern justly, to create equality and to instill in people good behaviour and high moral conduct. The concept of Saudi society as a conservative Moslem one based on an Islamic culture inherited from 1412 years ago, and which the State seeks strongly to preserve, is an integral part of planning and has occupied a major

(14) Ayman Al-Yassini, Religion and State in the Kingdom of Saudi Arabia, London: Westview Press. 1985, pp. 122-113.

(15) Ibid., p. 111.

(16) Al-Farsy, op. cit., p. 67

(17) Hisham M. Nazer, Lectures, "Third Development Plan", January 16, 1981, U.S.-Arab Chamber of Commerce (Pacific) Inc. New York, Riyadh: Ministry of Planning Press. 1981. p. 143. 
place as a policy framework in all five plans. Even though goods, services and technology have been imported from overseas for the furtherance of the plans and the country's modernization, the State has ensured that no foreign ideology has been imported. Islamic culture and modern planning are seen, through planning, as going hand-in-hand into the future.

\section{Social Traditions and Planning}

Nevertheless the nature of development brought on as a result of planning has already begun to challenge the traditional equilibrium of Saudi society. Indeed, Saudi Arabia has been undergoing dramatic social and economic change since its establishment in the 1930s. In fact, there are unpleasant aspects to change and sudden wealth. Saudis, nevertheless, do not seem anxious to return to the old life. Some of the older people still remember the anarchy and general insecurity of Bedoum society. Even though they still remember and revere their traditional homes - the simple houses and tents where those of the older generation were born and grew up - they also remember the austerity and difficulties of that time. Basic needs such as food and water were sometimes scarce and there was no organized welfare provision ${ }^{(18)}$. These strong memories of that suffering are not cherished and the pace of planning is driven by the need to provide the necessities of life for everyone in society as rapidly as possible. But even though urbanization has changed the Bedouin way of life, they still perceive of themselves as Bedouin tribesmen. And their values are retained even though their life has been changed by the modernizing process exemplified by having greater spending power, new technology, and education and job opportunities. Like many others, Saudis seem to want the benefits of science and technology whilst preserving something of their own traditions and identity. As stated previously, it is also the will of Ulama to accept technological devices and modern educational systems, but also to strictly monitor religious practices and social norms to ensure that the young adhere to traditional values. As Graham states:

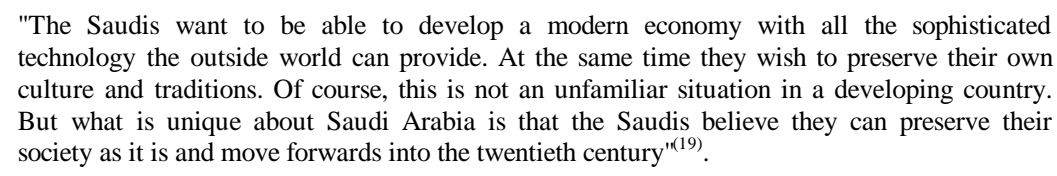
technology the outside world can provide. At the same time they wish to preserve their own culture and traditions. Of course, this is not an unfamiliar situation in a developing country. But what is unique about Saudi Arabia is that the Saudis believe they can preserve their society as it is and move forwards into the twentieth century"(19).

Of course, some contradictions do arise. Even though the Saudi Government has gone to great lengths to preserve the culture, traditions and identity of the people, and keep the Western presence from being visible, the signs of westernization are growing with motor cars, fashion and other such influences becoming more apparent. It is still true to say, however, that Saudis who have visited Western countries and who were keen to learn and to make the most of their opportunity for learning, seem unwilling to introduce Western values into Saudi society. The introduction of such Western commodities into Saudi Arabia has not affected its traditional values, customs and traditions, but have in fact been incorporated into them. This is confirmed by the exMinister of Planning, who has stated:

"The development process in Saudi Arabia was not imported into Saudi Arabia and imposed

(18) Ragaei EI-Mallakh and Dorothea H. EI-Mallakh, Saudi Arabia, Toronto: Lexington Books, 1982, p. 21.

(19) Robert Graham, "From Slumber to Riches: An Arabian Dream, New Middle East, No. 5, June 1973, London, p.16. 
upon our society. Our unique development process is derived from our total society in all its philosophic and religious and social richness" ${ }^{\prime 20)}$.

Saudi Arabia wants its people and each individual to progress, but without the moral degradation and social decadence linked to the predominance of materialistic values which so often accompany modernization. This worthy goal may appear to some people to be difficult to achieve; however, the Saudis believe their values are strong enough to achieve it, and despite what McLuan proclaimed in his study of the global village and the impact of mass media and ease of travel, the nations of the world continue to behave differently and according to their own national characteristics. Thus, Huyette emphasizes that:

"The French remain French and the Japanese remain Japanese and they show little desire to shed their national identity. Hence, it is entirely possible that the Saudis can maintain their own national character in spite of modernity and its by products"(21).

It can be argued that Saudi customs and culture could be an obstacle in the way of modern development. However, the modern Saudi society began with the discovery, extraction and processing of oil in the 1930s and was undertaken without the technology and skilled manpower of today. If Saudi Arabia was able to emerge successfully in such conditions, then it can certainly continue to flourish on a platform of imported modern technology, skilled and educated manpower, and its traditional values. The Saudi Government has, by its five plans, not only managed to strengthen the country economically, but also to maintain its distinctive society. Saudi Arabia has not become a Westernized state. Its traditional and religious values are too enshrined in its whole project for development. It is, therefore, not correct to compare institutions in Saudi Arabia with institutions of other countries, emanating from to tally different cultures and backgrounds, which would lead to wrong conclusions. As Alfarsy stated:

"I emphasise these tenets because some say their attachment to religious and social traditions slows the progress of development. This is not so, in two decades Saudi Arabia has moved from one century to another without violence" ${ }^{\text {(22) }}$.

From the above discussion, it can be concluded that national characteristics are part of society's values and way of life which affect the progress of planning. In fact, the use of Western technology and the encouragement of industry must not be taken as ends in themselves, but must be considered as a way of enhancing a country's total needs ${ }^{(23)}$.

To sum up, Saudi Arabia realized that modern technology and management methods are essential concomitants of planning to bring about development. In addition, it does not see any contradiction between modernization and the preservation of its heritage. In fact, the government took its philosophy from the experience of other countries, which were seen to have faced major social upheavals not as a result of planning and development in itself but because of the spiritual dissociation of the people from God, such as the experience of the countries in the communist bloc... Thus, the first aspect of planning in Saudi Arabia is the preservation of Islamic traditions, so that the importation of technology to improve the standard of living does not interfere with

(20) Nazer, op. cit., p. 144.

(21) Huyette, op. cit., 21.

(22) El-Mallakh, op. cit., p.21.

(23) M. Watson, and D. Humphreys, "Labour Approach to Planning: Economic V. Politics", West European Politics, London, Vol. 2, No. 2, May 1979, p.230. 
the Saudis relation with God.

In fact, technological improvement and economic progress are not the only reasons behind the rapid development of Saudi society, as the planning process has succeeded in integrating the whole of the country, by way of nationality, the language, culture and religion, towards the achievement of both economic and social goals. This appears to be in accord with what Killick states in his study of the possibilities of development planning:

"The type of society that appears to be the most amenable to development planning, then, is
a monastic one, as compared with a pluralistic society in which government policies respond
to and seek to adjudicate between competing group pressures"(24).

In addition, a major objective of planning in the Fifth Plan remains the preservation of the cultural heritage of an Islamic nation. In this respect Saudi planning has recognized that the problem with integrating foreign manpower, as in Germany, France and Great Britain, is a lesson to be learnt in order to avoid any conflict or instability in the Kingdom. It has established certain restrictive policies affecting all foreign manpower, such as not being allowed to have a permanent licence to work. Every foreigner in the country must have a sponsor. There are no incentives for foreign manpower to stay in the country or to own a home.

Saudi planning arose basically from the Government's will to utilize the wealth created by its oil resources to improve the standard of living throughout the country. In fact, Saudi Arabian planning seems to have the same objectives or concerns as Western countries in promoting a high rate of economic growth, the development of agriculture and industry, manpower skills, development of urban centres, the improvement of living conditions and fair distribution of income, in the context of an open economy retaining economic stability, control of inflation, and low unemployment.

Saudi planning can be distinguished from the Western and Soviet style planning, above all, by the influence on it of the Islamic religion, traditions and politics. These factors appear in all previous and current Five Year Plans and have become just as important as improving the social welfare of Saudi citizens, the preservation of national security and economic stability. Nevertheless, according to Algossibi, the former Minister of Electricity and Industry,

"the ultimate objective of the development efforts of the Saudi Arabian government is to maximize the welfare of the people at large within the shortest possible time without rupturing the religious and moral values of the country"(25)

Yet notwithstanding the commitment to develop the Saudi private sector, the government of Saudi Arabia seeks to safeguard the national interest through planning by correcting the social defects of the market mechanism. In this respect the approach is in keeping with Tawney's principle:

"industry is a form of Public service rather than constituted for the sole purpose of private gain" (my italic) ${ }^{(26)}$

(24) Tony Killick, The Possibilities of Development Planning, Oxford Economic Paper, Vol. 28:, No. 2, 1976, p.170.

(25) Enver M. Koury, "The Saudi Decision-Making Body", Hyattsvill, Middle East, Beirut: Institute of Middle Eastern and North African Affairs, 1978, p.55.

(26) Watson and Humphreys, op. cit., p. 231. 
A basic Principle of the Plan is to develop industry and agriculture through government policy for the benefit of the whole society. The government and its planners aim to embody the values of their citizens. However, they are very sensitive about not replacing the profit motive of the market by raison d'etat. The planners are therefore concerned with reconciling private and social interests by incorporating the objectives of both. The approach is to provide a reasonable basis for a social welfare function, which is considered to be in the general interest, along the lines that Heal states:

"the objective function in a planning problem serves to represent, or make numerically explicit, social preference" ${ }^{\prime(27)}$.

In fact, it is clear that the first responsibility of planning is to formulate a set of objectives and priorities as the basis for government economic and social policies and to have them articulated in public documents.

\section{Social Reaction}

The most striking change in planning sophistication and priorities, from the First Plan to the Fifth Plan is seen in the priorities for Saudi society i.e. social development. In fact, it can be deduced from the First Plan that it followed the social philosophy of the classic Western development theory, which specifies that economic development involves transforming the entire value system of a nation into a duplication of the Western ideal. In addition, the First Plan cautiously advised that manpower development programmes should take account of outside experts' reports, asking for measures to rectify the negative impact of Saudi social customs and tradition on the productive capacity of the labour force. However, it can be concluded from the Second, Third, Fourth and Fifth Plans that the planning moved in the direction of rejecting the popular Western idea that the two are incompatible: the highest priority has been given to protecting Saudi social values and achieving progress by incorporating them into the plans. The paramount objective of planning in Saudi Arabia is now given as a balanced development of the economic, social and cultural well-being of the nation.

In fact, most of Saudi citizens are Bedouin and the government's principal objective in development is to narrow the gap in social and economic welfare between the Bedouins and the rest of the Saudi population. The most significant administrative action to assure protection of Bedouin interest against the often conflicting interest of ministries was the establishment of a centralized department of Bedouin Development, which was charged with all aspects of Bedouin affairs.

The preceding plans in the last two decades acknowledged that any ministry charged with nationwide duties would tend to promote the interests of the whole above those of minorities and that, as stated in the Fourth Plan: indeed a minister would be somewhat derelict in his responsibilities to place one segment of the population before another in the consideration of the allocation of the specialized resources of his agency $^{(28)}$. The Ministry of Labour and Social Affairs is specifically responsible for promoting and studying the development of society as a whole.

In fact, there is a co-operative enterprise and organizations program within the

(27) Hillick, op. cit., p.167.

(28) Ministry of Planning, The Fourth Development Plan 1985-1990. Riyadh: 1985, p. 47. 
Ministry of Labour and Social Affairs, which is supposed, as an important part of planning development strategy, to multiply and diversify the number of co-operatives in which local people band together to achieve their aims at the local level. In 1970 there were already 37 programmes ranging from marketing to housing, electrification, and handicrafts. Each received a subsidy for the first five years of operation. Those that carried out social services such as care of the needy received, in addition, an annual social subsidy to cover the funds they expended on this function. The Fourth Five Year Plan laid out guidelines to increase the number of cooperatives and to encourage cooperative projects in which economies of scale are not a significant factor, such as housing and fishing. It also encouraged the setting up of electricity cooperatives on a regional basis to eliminate small power plants and local distribution systems in favour of larger, efficient, power plants on a regional level sharing electricity in a national grid. The functions of cooperatives include some of the financial services and some of society's public utilities, such as in the case of water and electricity. The cooperative approach is designed to distribute the benefits of national wealth to individual Saudi citizens. It also includes some of the municipal or society infrastructure services, such as transportation, sewage, flood control, construction of public markets and buildings, garbage collection, paving and street cleaning ${ }^{(29)}$.

Indeed, there are several components of the explanation of society's attitude.

A - The government development must consider the traditional and religious values. In this case the government ensures that the objectives and the strategic plans have as priorities the maintenance of social and religious values.

B - Society's attitude, in general, was very positive towards the planning process after it has realized that its traditions, religion and social well-being would be safe and come to no harm.

In fact, Saudi government leaders, though ideologically conservative, have made firm policy commitments, rooted in Islamic tradition, to deploy the country's resources to benefit the many rather than no further enrich the few and they have embarked on numerous programs to do just that. For instance, all health care and hospitalization is virtually free, comprehensive education through to the university level is also free, and grants are given to university students (students of religious education from the elementary school through to university level also receive free education and allowances are paid to them monthly). Any Saudi citizen, who qualifies to be admitted to a recognized Western University, can get government financial assistance to enable him to attend. In addition, any Saudi citizen could have free land to build a home and could also get an interest-free government loan of up to SR. 300,000. The citizen could also benefit from the plan's provisions for private sector developments and get the advantage of a wide range of incentives provided by the government ${ }^{(30)}$.

The government provides social services such as social security, in particular for physical aware "individuals in distress" because of their youth, age, physical infirmity or emotional instability which makes it impossible for them to take care of them selves. In fact, all Five Year Plans established several welfare programs including care for

(29) Ministry of Labour and Social Affairs, Mojmo 'at Nuzom, Riyadh: Matbaat Alkatab Altejarieh, 1984, pp. 27-51.

(30) Ministry of Finance and National Economy, Real Estate Development Fund, Annual Report, 1985. 
orphans, juvenile delinquents, and make relief payments, set up pensions arrangements and a rehabilitation programme for the retired. Training programmes for those who are rendered unemployed by the advances in technology are also provided by the Vocational Training Department of the Ministry of Labour and Social Affairs.

C - Most of Saudi society has become involved in planning and development in the sense that elders are encouraging the youth to take advantage of training provisions for modern technology, in line with the planning objectives and policies. Additionally, despite the fact that the Saudi government policy in education is that it is not compulsory, citizens have shown great eagerness for it, such that at times they could not find a place in the schools for their sons or daughters.

Altogether, it can be said that the traditions and customs of society have not acted in general as incommutable as obstacles to the planning process, in spite of the fact that Saudi Arabian society contains a great number of tribes, most of them being Bedouin, as they have been incorporated into the plan through the Ministry of Labour and Social Affairs.

\section{Conclusion}

The study of social values and Saudi planners show that the government and its planners are fully aware of the problems that Western and Eastern countries faced in their experience of industrialization. In fact, they do not see any contradiction between modernization and the preservation of social values. The government took its philosophy from the experience of other countries, which were seen to have faced major social upheavals not as a result of planning and development in itself but be cause of the spiritual dissociation of the people from God. Thus, the first aspect of planning in Saudi Arabia is the preservation of Islamic values. So that the importation of technology to improve the standard of living does not interfere with the Saudis' relation with God.

The planners are very keen not to damage the social values, and physical environment and have tackled problems regarding industrial safety and occupational health, traffic congestion, increasing tension for individual and family structure. Therefore, the Saudi planners are trying to provide for the development of society in the sense of raising the standard of living of the whole population while maintaining the Saudi way of social and cultural life.

In fact, there are several reasons behind the successful planning in Saudi society, such as, the sufficient political will to modernize the country along a definite path, namely keeping national unity by ensuring the spread of prosperity, extending social welfare and safeguarding religion and customs. Also there has been support for such development from the people themselves, whose aspirations were closely reflected in those of the government, and their commitment to the planning process has been significant in that modernization is being achieved without great upheaval and the stability of society is being retained. 


\section{References}

Ashore, Ahmed S., Public Administration, Beirut: Dar Alnahdah Alarabia, 1979.

Baldwin, Claude D., Economic Planning, Urbana: The University of Illinois Press, 1942.

Bruton, M. J., The Spirit and Purpose of Planning, London: Hutchinson and Company Ltd., 1974.

Dror, Yehezkel, Ventures in Policy Science, N.Y.: American Elsevien Publishing Company, 1970.

Faris, Hani A., "Heritage and Ideologies in Contemporary Arab Thought: Contrasting Views of Change and Development", Journal of Asian and African Studies, XXI 1-2, 1986.

AI-Farsy, Fouad, Saudi Arabia: A Case Study in Development, London: Stacey International, 1978.

Graham, Robert, "From Slumber to Riches: An Arabian Dream", New Middle East, London: No. 5, June 1973.

Hayward, Jack and Watson, Michael, Planning Politics and Public Policy, London: Cambridge University Press. 1975.

Huyette, Summer Scott, Political Adaptation in Saudi Arabia: A Study of the Council of Ministers, London: Westview Press, 1985.

Killick, Tony, The Possibilities of Development Planning, Oxford Economic Paper. Vol. 2, No. 2, 1976.

Koury, Enver M., The Saudi Decision-Making Body, Hyattsvill, Middle East, Beirut: Institute of Middle Eastern and North African Affairs, 1978.

EI-Mallakh, Ragaei and EI-Mallakh Dorothea H., Saudi Arabia, Toronto: Lexington Books, 1982.

Ministry of Finance and National Economy, Real Estate Development Fund, Annual Report, 1985.

Ministry of Labour and Social Affairs, Mojmo `at, Nuzom, Riyadh: Matbaat Alkatab Altejarieh, 1984 (in Arabic).

Ministry of Planning, The Fourth Development Plan 1985-1990, Riyadh, 1985.

Nazer, Hisham M., Lectures, "Third Development Plan", January16, 1981, U.S.-Arab Chamber of Commerce (Pacific) Inc., New York, Riyadh: Ministry of Planning Press, 1981.

Watson, M., and D. Humphreys, "Labour Approach to Planning: Economic V. Politics", West European Politics, (London), Vol. 2, No. 2, May 1979.

AI-Yassini, Ayman, Religion and State in the Kingdom of Saudi Arabia, London: Westview Press, 1985. 


$$
\begin{aligned}
& \text { التخطيط و القيم الاجتماعية } \\
& \text { طلال مسلط عبدالله الشريف } \\
& \text { أستاذ مساعل مساط عبله } \\
& \text { قسم الإدارة العامة - كلية الاقتصاد والإدارة }
\end{aligned}
$$

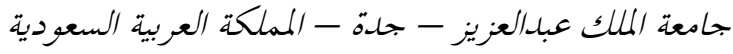

المستخلص: عندما قررت المملكة العربية السعودية الأخهـ بمبــأ التخطيط كـان الهـدف منـهـ

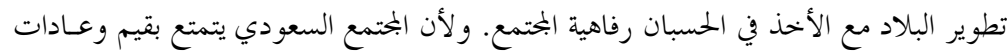

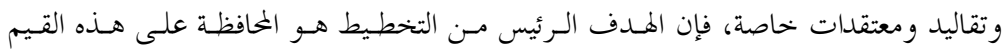

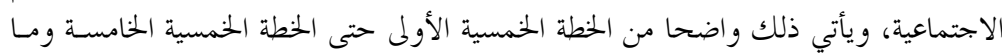
يأتي بعدها من خطط.

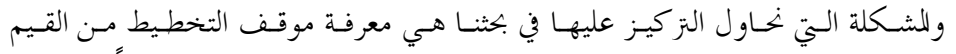

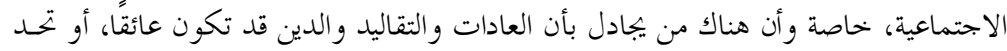

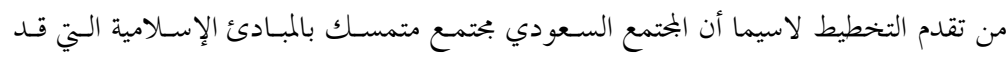
يكون لها دور في التأثير على التخطيط. لتسط.

$$
\begin{aligned}
& \text { إن الغاية من هذا البحث هي دراسة الأهداف التالية: } \\
& \text { ا - تقويم القيم الاجتماعية كعامل يحد أو يؤثر على التخطي التهيط. } \\
& \text { r - معرفة استجابة البحتمع السعودي للتخطيط. } \\
& \text { r- دراسة دور التخطيط في المحافظة على القيم الاجتماعية. }
\end{aligned}
$$

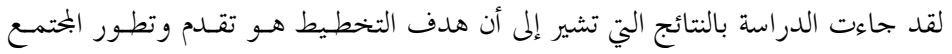

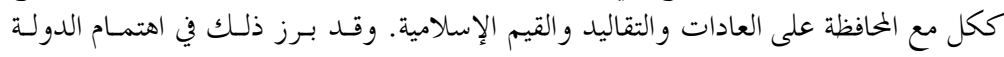

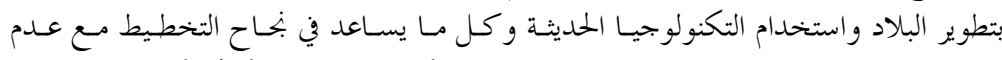

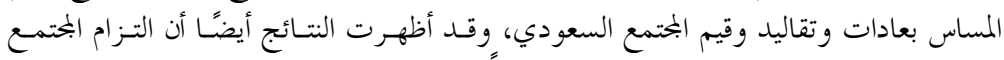

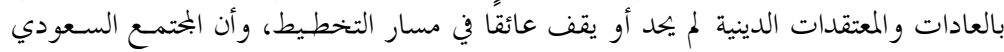
شارك و ساهم في بحال التخطيط. 